\title{
VALUE MANAGEMENT OF THE RISKS FOR THE IMPLEMENTATION OF FAST-TRACKING (SDFT) CONSTRUCTION PROJECTS
}

\author{
Amira Hashem*, Akram farouk, and moataz Abd El-Fatah \\ Department of Architecture Engineering, Faculty of Engineering, \\ Ain Shams University, Cairo, Egypt. \\ *Corresponding Author E-mail::Amirahilal73@gmail.com
}

\begin{abstract}
:
Purpose: The purpose of this paper is todefine and analyse the factors of risks, which have bad impact on fast track project's goals in Egypt (cost, Quality, time ), by using value and risk analysis's strategies together.

Design/methodology/approach: This research used three technique to collect data, the first on is a comprehensive questionnaire survey, the second one is interviews, and the third one is a brainstorming session with major construction project stakeholders. Then research used qualitative technique to analysis their responses to find the most critical risks, and value strategies to make alternative solution which help stakeholders to deal with risks and achieve project's cost, time and Quality

Findings: The findings lead to the conclusion that there is a need to develop management system, which combine between value management and risk management, to help stakeholders to make the right decision as early as possible to deal with risks. In addition, the results showed that there are common and critical risks, which must take care about it from the first stage in fast track' 1 construction in Egypt to suggest pervious alternative solutions to save project's value and goals. Originality/value: The paper identifies current fast track project's risks in Egypt and presents alternative solutions, which can help stakeholders to overcome them.
\end{abstract}

\section{KEYWORDS: Risk Management, Value Management, Fast Track Projects, Short Duration, Combining, and Implementation.}

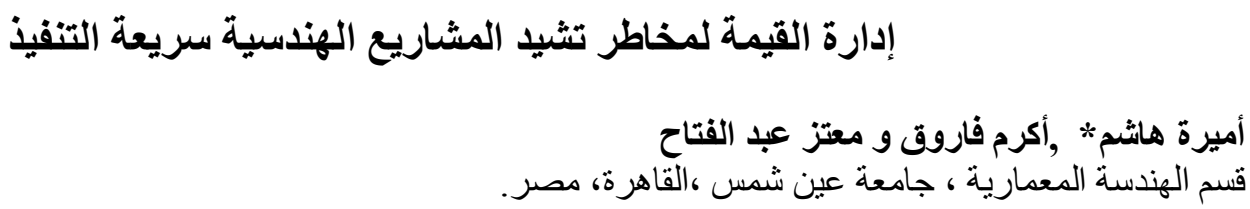
E-mail: Amirahila173@gmail.com البريد الاليكتروني للباحث الرئيسية

\footnotetext{
الغرض من هذه الورقة: هو تعريف و تحليل عوامل المخاطر ، التي لها تأثير سيء على أهداف مشروع المسار السريع في

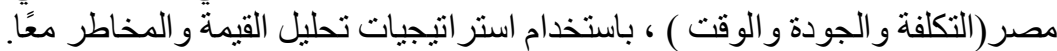

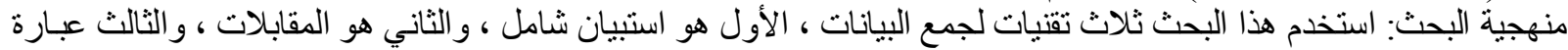

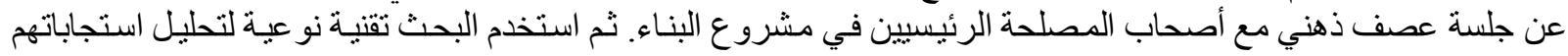




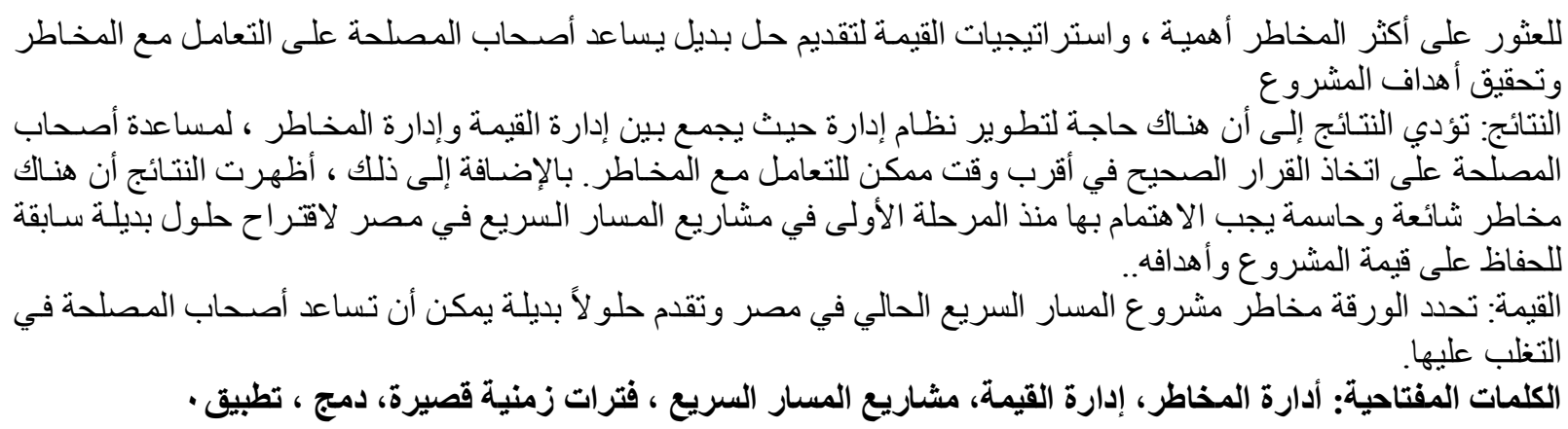

In light of the Egyptian and international government policies since 2014, the responsible authorities initiated the importance of the value of time in a very decisively way to achieve national projects in Egypt to keep pace with the world and its rapid developments. So responsible authorities accelerated (fast tracking)nationalprojects,Meaning that projects that take three years to implement will complete within a year.

So it has become very important to understand how to deal with fast track technique and its risks to save project's value and goals. In addition, how to use management as a tool with risk management to success the construction projects; especially that projects which have high probability of risks as Fat track projects

\section{LITERATURE REVIEW}

Short duration fast track (SDFT)is a planning strategy, which used to decrease the overall duration of projects by overlapping tasks that on a traditional contract. The most time to save by overlapping the design and construction stages.

In 1988, Fazio found that the traditional project delivery system failing to meet the present challenges, so owners found it necessary to become more involved in management of their projects. In an effort to shorten project durations and help meet overall project objectives, fasttracking management techniques have been developed as part of the professional construction management (PCM) approach , as shown in figure (2.3).
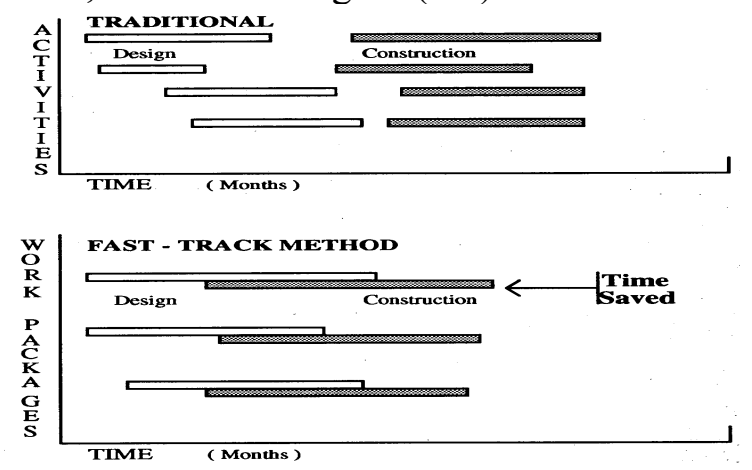

Figure (2.3): Traditional and Fast Track Construction (Fazio, 1988)

In 2017, Matt Lovelessfound that using fast track technique is more than just rushing it is a very different systematic process than traditional process to achieve project's goals. Fast track system defines as overlapping the construction stages of the project and the activities in an effort to decrease the total project's time required to finish.As shown in figure (1.2) 


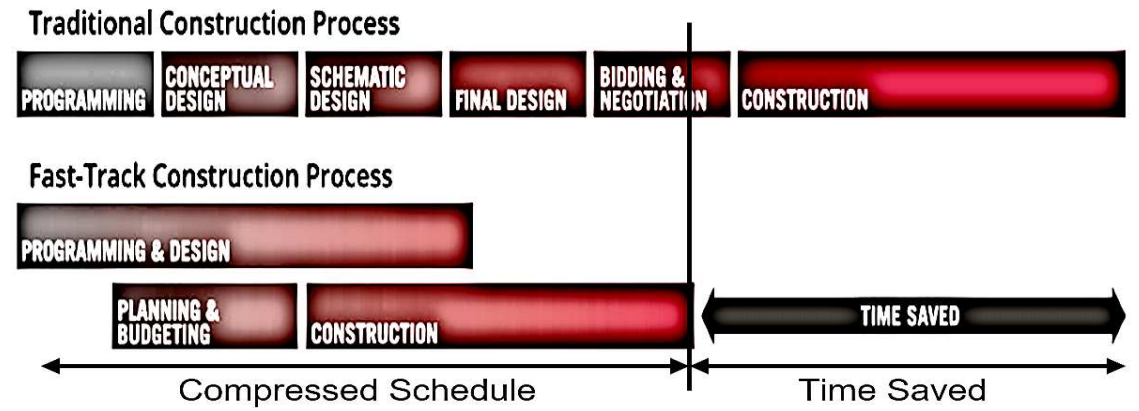

Figure (1.2): Traditional vs Fast track planning, SourceMatt Loveless, 2017

According to (PMBOK ${ }^{\circledR}$ Guide Sixth Edition, 2017), In fast track technique acceleration ordinarily increases coordination efforts between the activities, and increases risks and may too increase project costs than normal technique as shown in figure (1.1).

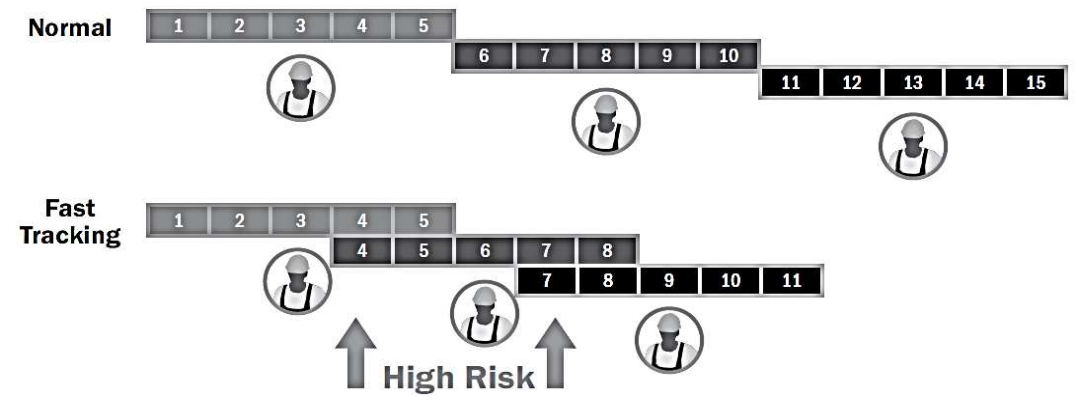

Figure (1.1): Normal and fast racking technique, Source: PMBOK®Guide Sixth Edition, 2017

Therefore,Stakeholders cannot achievesuccess in fast track projects within the absence of careful risk evaluation and proactive risk management at the valuation and execution stages. Project's net return and risks are the two essential factors that decide its ultimate success and the value it delivers (Ralph Dandrea, 2006). Inaddition, In 2006 Dallas find that Value and risk management together enables organizations to succeed within the delivery of projects where maximize value and minimize uncertainty, to form successful delivery forms that minimize the impact of the unexpected and uncertainties. Therefore, it isnecessary to understand the value management. And how to use value and risk management together toachieve projects goals

Value engineering started at Common Electric Co. during World War II. Since of the war, there were shortages of skilled labor, crude materials, and component parts. (Lawrence Miles, Jerry Leftow, and Harry Erlicher at G.E.) Looked for acceptable substitutes, they taken note that these substitutions frequently reduced costs, improved the item, or both, what begun out as an mischance of need was turned into a systematic process they called their strategy "value analysis" (Miss Apurva J Chavan , 2013). Moreover, In 2000 PMBOK 4th edition defineValue engineering (VE)as structure technique commonly used in project management, an organized attempt to optimize the overall value of the project in project management endeavors.In addition,Aims to use creative strategies to achieve the lowest life cycle cost available for the project, the stakeholders must consider all costs related with the project, from the starting plan of the item or benefit through its possible disposal.

Finally according to (Ray R. Venkataraman, 2008) Combining Risk and value management processes into a single and formal coordinate's process is a great technique that can maximize project value and return whereas decreasing uncertainty. According to (Major, Emma. 2003) Value Management is concerned with resolving the uncertainty within the project targets, Risk Management is concerned with resolving the uncertainty within the project, so in the fact value and risk management two sides of the same coin. 


\section{RESEARCH GOALS}

The main goal of research to define, analysis and evaluate risks on fast track project in Egypt by value, risk management strategies, then recommend the most critical risks in fast track projects in Egypt and alternatives response to deal with itto achieve the best Quality and lowest cost at the specific time .

This research aims to identify the most risks, which have bad effects on SDFT projects in Egypt. Identifying these variables can help to accurately evaluation the specified risks, which ought to be included to avoid in next fast track projects in Egypt

\section{RESEARCH SCOPE}

The research selected three cases study with limited specifications as following:

1. National projects in Egypt

2. Fast tracking projects

3. Government (Armed forces) as the owner of project

4. Planned Time of projects between $(10-12)$ month

5. Total project cost between (.5 billion -2 billion )

6. Projects have the same Quality

The research consider all factors constant except time and cost,as Quality of project and economic factors in execution and that's due to the owners' Specificationsand Requirements in this type of projects.

The research selected limited specifications in responders to collect data and information through interview and Questionnaires as following:

1. Project manager

2. Cost control engineer

3. Planning engineer

4. Quality control engineer

Due to Government constrains ,there is not available any numerical or schedule as a details data to use Quantitative analysis in study, the research-selected Qualitative analysis to find results for each project, and collected data from interviews and Questionnaires .

The research used value management as a tool of risk management to find response plans for critical risks, which already happened in case studies0

\section{RESEARCH METHODOLOGY}

The research selected three national fast track projects in Egypt, and then collected data from interviews and Questioners. Then analysed results by Qualitative Strategy to find the critical risks, then used value management to response alternative solutions for risks, finally recorded the recommendations of using fast track technique in Egypt.

Select National cases study in egypt

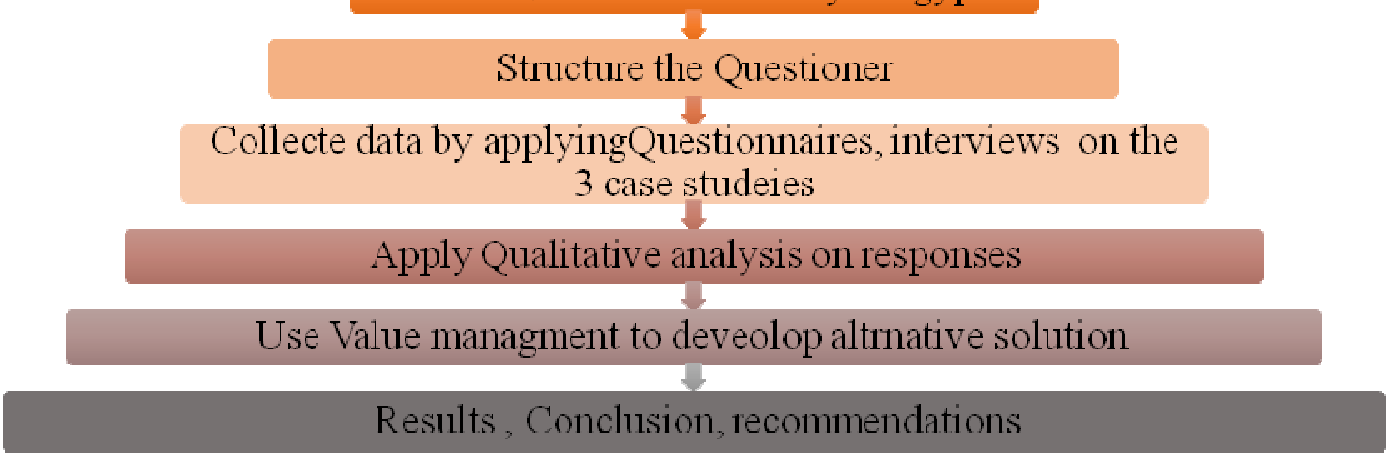

Questionnaire structured on literature review of risk break down structure, as According to (Miller, 2000) Risks primarily divided as internal risks and external risks. According to (Kristen 
Barlish, 2013) taxonomy matrix divided risks to 3 levels, Level one classifies the risk as either internal or external to the construction vendor, level two categorizes the risk according to its source or organization responsible and level three captures the detail as shown in figure (1.3).

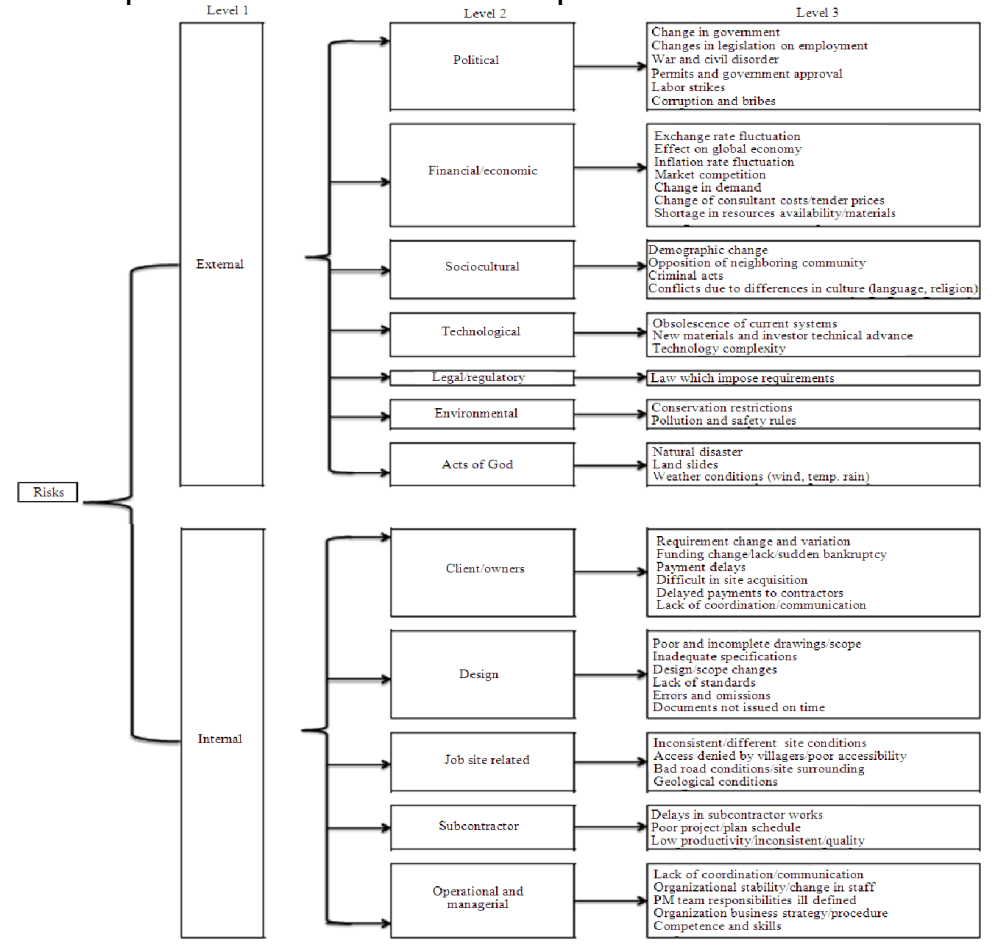

Figure (1.3): taxonomy matrix,Source: Kristen Barlish, 2013

According to (El-Sayegh, S. ,2008) Risks divides to 2 main types (internal and external risks) then divide the internal risks to 5 types and external risks to 5 types ,as following figure (1.4). 


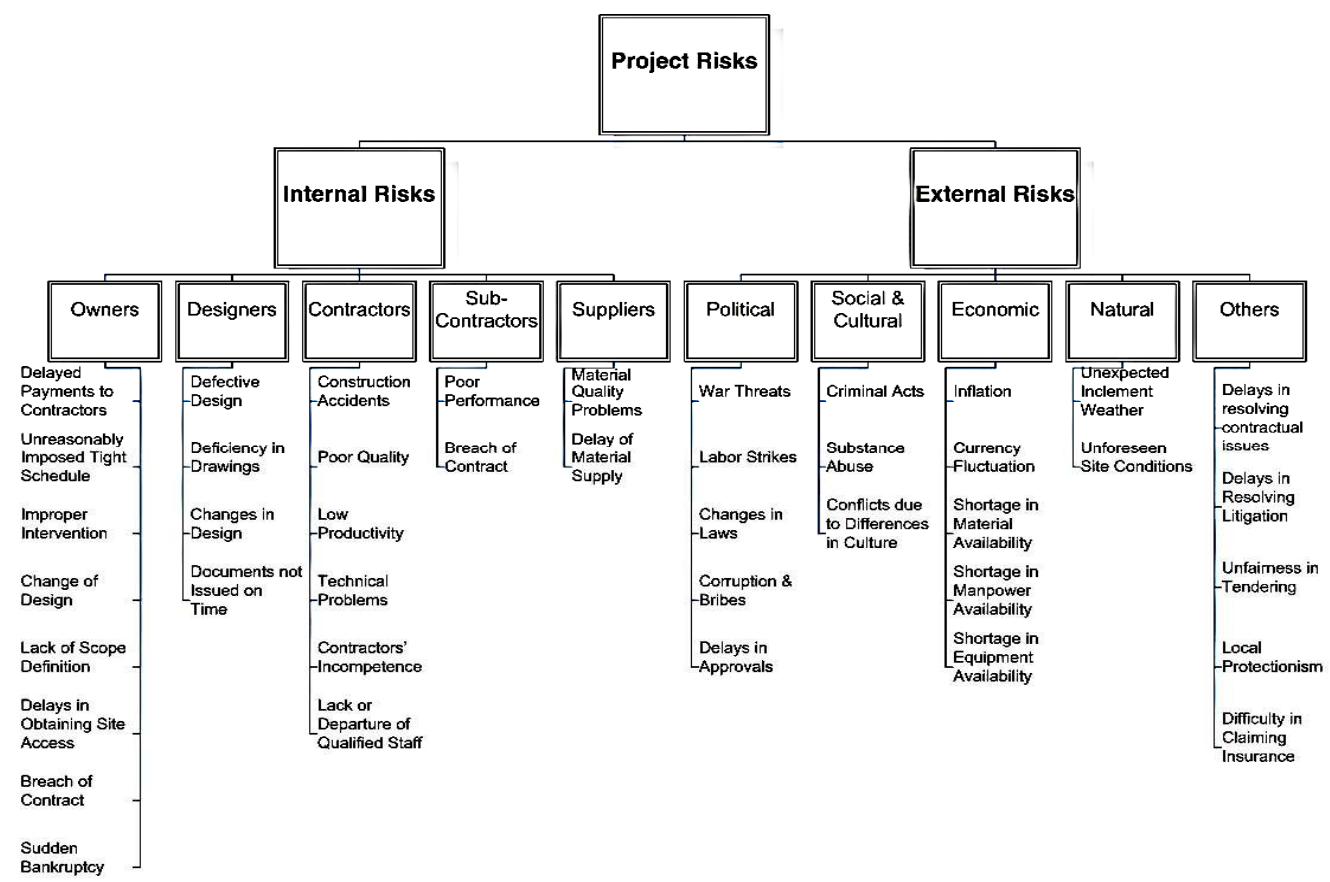

Figure (1.4): risk break down structure, Source: El-Sayegh, S., 2008

\section{DATA COLLECTION}

Research collect all data, which used in Qualitative analysis from the engineers who worked on the projects of case studies by Questionnaires and interviews

Source of date:Project managers of projects, Cost control engineers, Planningengineers, Quality control engineers.

Research collectedthree main categories of risks divided to 10 factors then 49risk based on literature review as figure (1.3), (1.4). Then research structured twoQuestioner, the first on aims to rank risks by its impact rate and probability, and the second one aims to identify risk's response and its alternative solutions to deal with this risks.

\section{A. RISKS FACTORS , RISK BREAK DOWN STRUCTURE (RBS)}

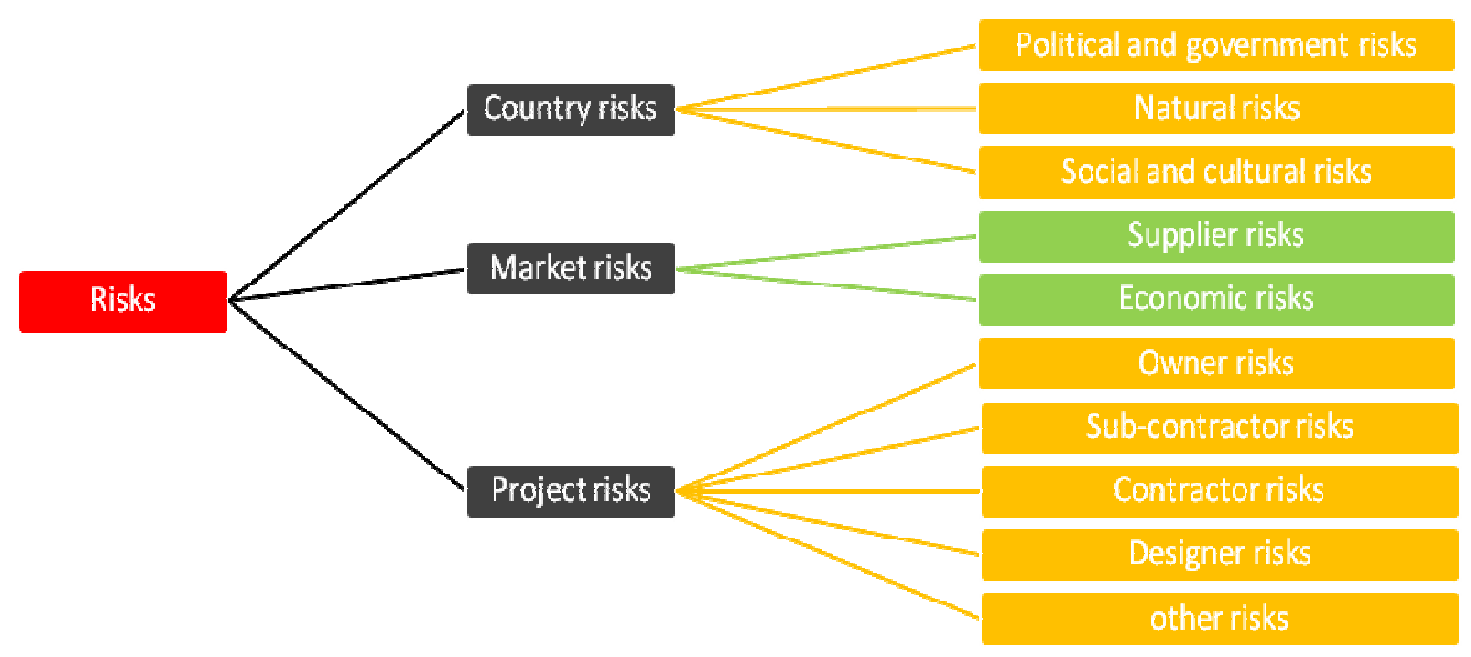




\section{B. QUESTIONER ONE TECHNIQUE}

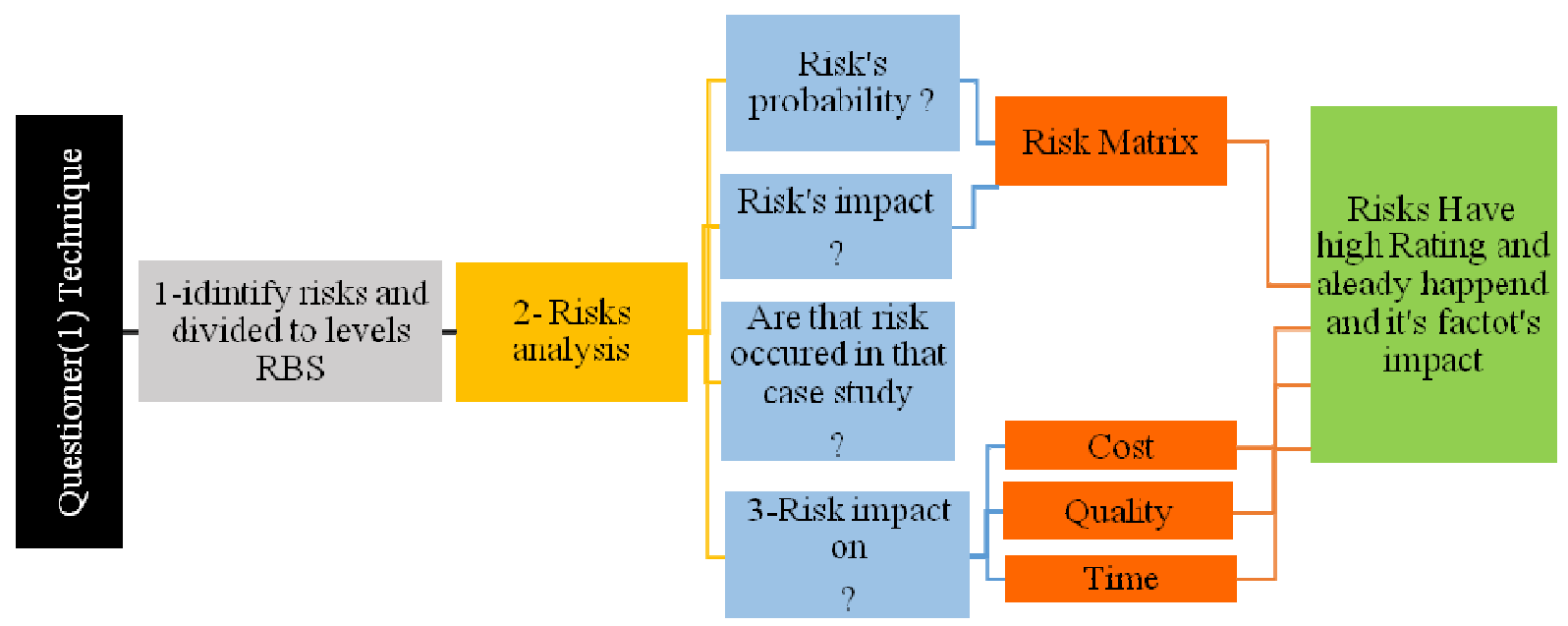

\section{Questioner TWo TeChNiQue}

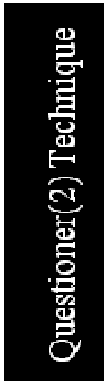

Risks Have ligh Rating and aleady happend and it's factot's impact
Response plans that alrcady

immplemmented in case study
Record altinative solution to deal with risks in FTSD projects

\section{SELECTED CASES STUDY}

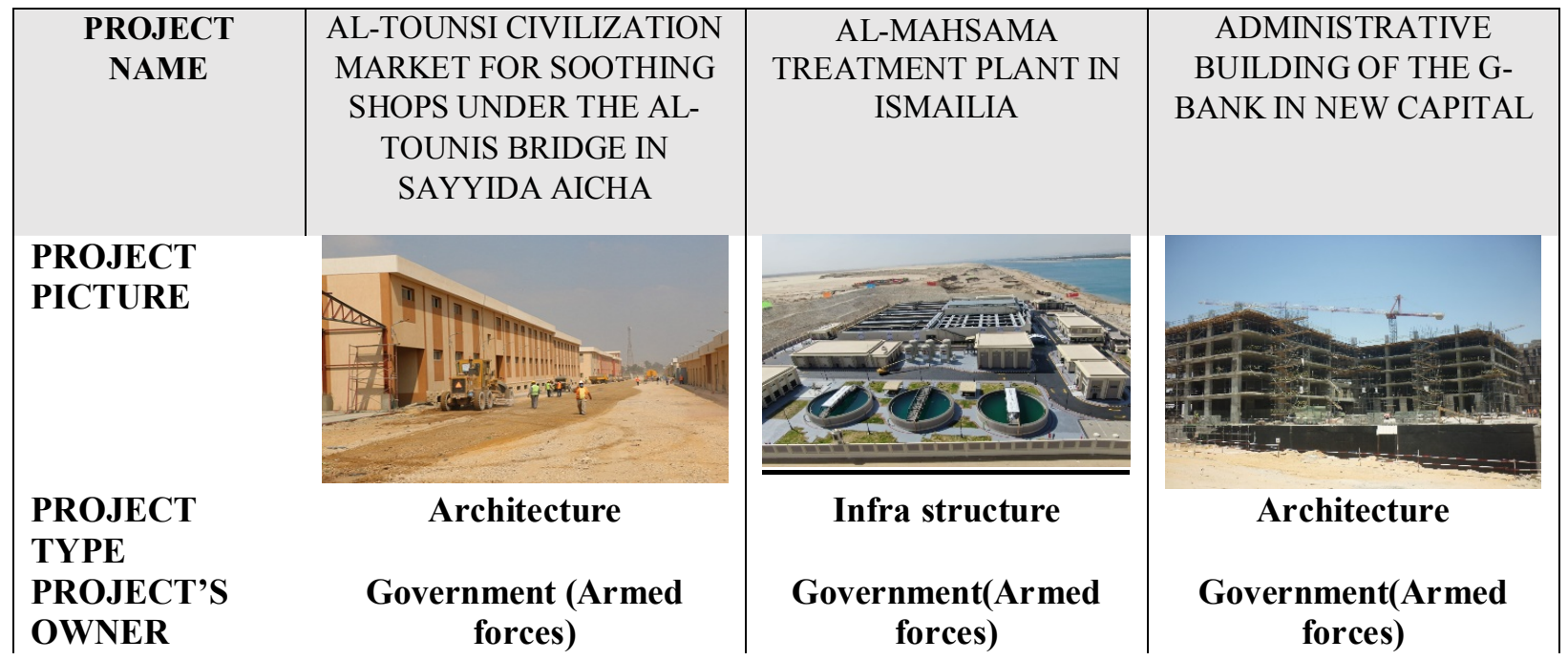




\begin{tabular}{|lc|c|c|}
$\begin{array}{l}\text { PROJECT'S } \\
\text { CONTRACTOR }\end{array}$ & $\begin{array}{c}\text { Arab Contractors } \\
\text { Osman Ahmed Osman }\end{array}$ & Hassan Allam holding & Hassan Allam holding \\
$\begin{array}{l}\text { CONTRACT } \\
\text { TYPE }\end{array}$ & lump sum & lump sum & lump sum \\
TOTAL COST & 500 million pounds & 1.7 billion pounds & 1.8 billion pounds \\
$\begin{array}{l}\text { PLANNED } \\
\text { START }\end{array}$ & $1 / 08 / 2017$ & $15 / 08 / 2018$ & $1 / 11 / 2019$ \\
$\begin{array}{l}\text { PLANNED END } \\
\text { PLANNED }\end{array}$ & $1 / 07 / 2018$ & $15 / 06 / 2019$ & $1 / 11 / 2020$ \\
$\begin{array}{l}\text { DURATION } \\
\text { ACTUAL }\end{array}$ & 11 months & 10 months & 12 months \\
$\begin{array}{l}\text { START } \\
\text { ACTUAL END }\end{array}$ & $1 / 08 / 2017$ & $01 / 05 / 2018$ & $01 / 12 / 2019$ \\
$\begin{array}{l}\text { ACTUAL } \\
\text { DURATION }\end{array}$ & $1 / 6 / 2020$ & $19 / 11 / 2019$ & $1 / 2 / 2021$ \\
TOTAL FLOAT & -1 year and 11 months & -8 months & 1 years and 2 months \\
$\begin{array}{l}\text { NO OF RISKS } \\
\text { IN PROJECT }\end{array}$ & 11 Risks & 9 Risks & -2 months \\
\hline
\end{tabular}

\section{CASES STUDY'S RESULTS}

The study finds that there are common risks between case studies, which the stockholders must be care about it before any fast track projects, in addition to that the study suggested alternatives plans to deal with that risks such as:

\begin{tabular}{l|l|c|c}
\hline Risk (1) & $\begin{array}{l}\text { Frequent changes of design by designers and change orders } \\
\text { during executing stage }\end{array}$ & $\begin{array}{l}\text { Risk Rating } \\
\text { We can avoid change orders like this by starting the project with a complete design. More } \\
\text { Alternative 1 } \\
\text { construction in the design will mean that there is a much smaller chance of change orders once } \\
\text { constion commenced. }\end{array}$
\end{tabular}

Alternative 2

Add a document in contract that establishes the process for initiating, authorizing, performing, and paying change order work to prevent some unauthorized change orders from requesting. Additionally, especially when the change orders include unnecessary requests.

Ask owner and designer to be sure of the designs to avoid changing in designs because of

Alternative 3 the contractor's planned plans of martial or schedule or Quantity and it's cost, and put constrain item to limit changes in designs, only available critical changes that may have bad impact on Quality or may be become risky on building objective

Risk (2 ) Low productivity of labor

Submission of labors training Programs to improve their productivity rate to be more

Alternative 1 effective on project's success and force labors to work with the new systems.

Set Goals for labors and provide performance-based Incentives by adding unexpected bonus to labors also adding employee health programs are also effective because a healthy

Alternative 2 workforce is simply more productive and naturally motivated. They use fewer sick days and maintain the ability to perform labor tasks across the year with fewer injuries or issues. 


\begin{tabular}{|c|c|c|c|}
\hline \multirow{2}{*}{$\begin{array}{l}\text { Alternative } 3 \\
\text { Risk ( } 3 \text { ) }\end{array}$} & \multicolumn{3}{|c|}{$\begin{array}{l}\text { Due to the limit time of fast track project, project team must employ very skilled labor, and } \\
\text { take strict decisions if they do not achieve planned target and monitoring them. }\end{array}$} \\
\hline & $\begin{array}{l}\text { Risks Due to lump sum contract contractor cannot take } \\
\text { back that cost because the Type of contract (There is a } \\
\text { higher risk for the contractor). }\end{array}$ & 0.40 & Avoid \\
\hline Alternative 1 & \multicolumn{3}{|c|}{$\begin{array}{l}\text { Adding an item in the contract that the contractor has the right to add an addendum } \\
\text { contract if unexpected critical risks for all stakeholders occurred which increases the cost } \\
\text { of the project }\end{array}$} \\
\hline Alternative 2 & \multicolumn{3}{|c|}{$\begin{array}{l}\text { Adding an item in the contract that the contractor has the right to share unexpected risks } \\
\text { between owner and contractor }\end{array}$} \\
\hline Alternative 3 & \multicolumn{3}{|c|}{$\begin{array}{l}\text { Adding an item in the contract that the contractor has the right to transfer all unexpected } \\
\text { risks' impact on project to owner to take action, even if it will impact on cost or time }\end{array}$} \\
\hline Risk ( 4 ) & $\begin{array}{l}\text { Lack of communication and consistency in decisions } \\
\text { between the owner, the consultant, and the contractor }\end{array}$ & 0.20 & Mitigate \\
\hline Alternative 1 & \multicolumn{3}{|c|}{ Weekly meetings between contractor and owner and designer to keep staff updated. } \\
\hline Alternative 2 & \multicolumn{3}{|l|}{ Clearly identify roles and responsibilities of team members. } \\
\hline Alternative 3 & \multicolumn{3}{|c|}{$\begin{array}{l}\text { Ensure the proper connections and functioning networks are available even in very remote } \\
\text { sites. }\end{array}$} \\
\hline Al & \multicolumn{3}{|c|}{$\begin{array}{l}\text { Use up-to-date digital solutions, which allow communicating with the other members of the } \\
\text { team regardless of the type of device you are using. }\end{array}$} \\
\hline
\end{tabular}

\section{CONCLUSION OF RESEARCH}

1. Fast-Track projects cannot be adequately handled by Design and Build or Novation, even though these processes does have potential to save some time compared with the traditional contract which separates entirely the process of design and construction. Therefore, project management must be qualify and readily able to accommodate changes during design, during construction and after construction. In order to assist in assessing the cost and buildability of the various alternatives, regular

2. Understanding the relationship between value and risk management factors that drive FastTrack construction to success and dealing with all-risk's impacts, all of this will facilitate managing Fast track projects in a way that increases client satisfaction and enhances the performance of the project.

3. Project management must be qualify and readily able to accommodate changes during design, during construction and after construction. In order to assist in assessing the cost and buildability of the various alternatives, regular consultation needed with subcontractors regarding alternatives, particularly in regards to form work.

4. Other factors, which may need to be taken into, account when deciding on the method ofto be used is the availability of competent contractors within the local market that could provide competitive tenders

5. Fast track or schedule-driven projects have significantly more claims than conservatively scheduled projects.

6. When we look at the frequency of claims associated with risk, there is a clear distinction. Lump sum, which transfers the greatest amount of risk to the contractor, has a much higher frequency of claims. 


\section{REFERENCES}

1. A guide to the project management body of Knowledge ((Pmbok ${ }^{\circledR}$ Guide), Sixth Edition, PMI, (2017). Newtown Square, Pennsylvania 19073-3299 USA, Pa: Project Management Institute.

2. Project Management Institute, A Guide to the Project Management Body of Knowledge (PMBOK Guide), fourth ed., PMI, Pennsylvania, USA, 2000.

3. Ray R. Venkataraman,,and Jeffrey K. Pinto, (2008)." Cost And Value Management In Projects". John Wiley \& Sons, Inc.

4. Major, E. (2003).Value And risk management study. Paper presented at PMI ${ }^{\circ}$ Global Congress 2003-EMEA, The Hague, South Holland, The Netherlands. Newtown Square, PA: Project Management Institute.

5. Miller, J.B. (2000). "Principles of public and private infrastructure delivery". Boston: Kluwer Academic Publishers

6. Kristen Barlish, Alberto De Marco and, Muhammad JamaluddinThahee. (2013)." Risk taxonomy: an international convergence of academic and industry perspectives, American Journal of Applied Sciences 10 (7): 706-713, 2013

7. El-Sayegh, S. (2008). Risk assessment and allocation in the UAE construction industry. International Journal of Project Management, 26, 431-438.

8. Ralph Dandrea " (2006 )Increasing Project Value through Risk Management,

9. Dallas, M. F. (2006). Value and Risk Management: A Guide to Best Practice. Oxford, UK: Blackwell

10. Matt Loveless , 2017, No Construction Left Behind: Fast-Track, SummerRenovationwinter-construction.

11. Apurva J Chavan , (2013),"Value Engineering In Construction

12. Industry" International Journal of Application or Innovation in Engineering \& Management (IJAIEM)Web Site: www.ijaiem.org 